\title{
Validation of the urgency questionnaire in Portuguese: A new instrument to assess overactive bladder syndrome
}

Rodolfo Pacheco de Moraes ${ }^{1}$, Jonas Lopes da Silva 2, Adriano Almeida Calado 2, Geraldo de Aguiar Cavalcanti ${ }^{2,3}$

${ }^{1}$ Divisão de Urologia, Hospital da Polícia Militar de Pernambuco (PMPE), Recife, PE, Brasil; ${ }^{2}$ Divisão de Urologia, Hospital Universitário Oswaldo Cruz - Universidade de Pernambuco (HUOC-UPE) Santo Amaro, Recife, PE, Brasil; ${ }^{3}$ Divisão de Urologia, Departamento de Cirurgia - Universidade Federal de Pernambuco (UFPE) Cidade Universitária, Recife, PE, Brasil

\section{ABSTRACT}

Purpose: Overactive Bladder (OAB) is a clinical condition characterized by symptoms reported by patients. Therefore, measurement instruments based on reported information are important for understanding its impact and treatment benefits. The aim of this study was to translate, culturally adapt and validate the Urgency Questionnaire (UQ) in Portuguese.

Materials and Methods: Initially, the UQ was translated and culturally adapted to Portuguese. Sixty-three volunteers were enrolled in the study and were interviewed for responding the Portuguese version of the UQ and the validated Portuguese version of the Overactive Bladder Questionnaire short-form (OABq-SF), used as the gold standard measurement for the validation process. Psychometric properties such as criterion validity, stability, and reliability were tested. Results: Forty-six subjects were included in the symptomatic group (presence of "urgency"), and seventeen were included in the asymptomatic group (control group). There was difference between symptomatic and asymptomatic subjects on all of the subscales $(\mathrm{p} \leq 0.001)$. The UQ subscales correlated with the $0 \mathrm{ABq}-\mathrm{SF}$ subscales $(\mathrm{p} \leq 0.01)$, except the subscale "time to control urgency" and the item "impact" from the visual analog scales (VAS). However, these scales correlated with the OABq-SF - Symptom Bother Scale. The UQ subscales demonstrated stability over time $(\mathrm{p}<0.05)$, but the subscale "fear of incontinence" and the item "severity" of the VAS did not. All of the UQ subscales showed internal consistencies that were considered to be good or excellent. Conclusion: The Portuguese version of the UQ proved to be a valid tool for the evaluation of $\mathrm{OAB}$ in individuals whose native language is Portuguese.

\section{ARTICLE INFO}

\section{Keywords:}

Urinary Bladder, Overactive; Validation Studies [Publication Type]; Urinary Incontinence; Psychometrics

Int Braz J Urol. 2017; 44: 338-47

Submitted for publication:

March 10, 2017

Accepted after revision:

June 17, 2017

Published as Ahead of Print: November 30, 2017

\section{INTRODUCTION}

The term overactive bladder $(\mathrm{OAB})$ was first proposed by Wein and Abrams to describe "urgency" and "urge-incontinence" symptoms (1). The syndrome is currently defined as the presence of urinary urgency with or without incon- tinence, usually associated with increased urinary frequency and nocturia, in the absence of an urinary tract infection or other diseases (2). Overactive bladder is a clinical condition with a high prevalence in the general population, with values ranging from $10.8 \%$ to $46.9 \%$ depending on the population studied and definitions used for the 
diagnosis (3-5). Community surveys in the United States and Europe indicate that symptoms of $\mathrm{OAB}$ are common among both male and female adults, being more prevalent in women than men (30$40 \%$ versus $15-30 \%)$. OAB in men can be secondary to Bladder Outlet Obstruction $(6,7)$.

The use of standardized patient-reported outcomes in clinical practice has been shown to improve communication between patients and physicians and may improve the process of treatment selection (8). The usefulness of patient-reported outcomes as a measure of treatment effectiveness, which are collected using a previously validated tool, depends on the tool's psychometric properties. Currently, the Overactive Bladder Questionnaire $(\mathrm{OAB}-\mathrm{q})$ is the only questionnaire to evaluate the overactive bladder that has been validated to Portuguese (9). The King's Health Questionnaire has also been validated to Portuguese. However, it evaluates mainly the quality of life regarding the presence of urinary incontinence $(10,11)$. Other questionnaires have been described for overactive bladder, but few value the urinary urgency symptom or are very simple and may not represent the reality of the $\mathrm{OAB}$ syndrome (12).

As there are no universally accepted measures for urinary urgency, this new tool could contribute to the evaluation of the impact of $\mathrm{OAB}$, associated or not with urinary incontinence. The "Urgency Questionnaire" (UQ) was proposed by Coyne et al. (13) to assess the context, severity, intensity, and daily life impact of urinary urgency, the cardinal symptom of OAB.

The aim of this study was to translate, culturally adapt and validate the UQ in Portuguese in order to quantify the impact of urinary urgency on the quality of life of patients with $\mathrm{OAB}$.

\section{MATERIALS AND METHODS}

\section{Translation and cultural adaptation}

After receiving authorization from the questionnaire's author, the standard method for survey validation was followed in accordance with adapted international criteria (14) and previously completed validation studies $(9,15,16)$.

First, three versions of the UQ were provided by three Portuguese-speaking translators who were fluent in English, and an agreed-upon version in Portuguese was developed by the authors.

Secondly, the translated version was back-translated to English by three translators whose native language was English and were also fluent in Portuguese. The translators were blind to the purpose of this study. An agreed-upon version of the English back-translation was developed and reviewed to ensure that the original content had been maintained and to reveal inconsistencies with the Portuguese version.

Upon the completion of the translation process, a review committee composed by three urologists specialized in voiding disturbances with bilingual professionals created idiomatic and cultural adaptations of the version.

This version was completed after its implementation in a pilot study to determine its cultural appropriateness, and each question was followed with the expression, "I did not understand the question”, as written by Calado et al. (17). After analyzing the data related to the respondent's ability to understand the questionnaire, a final Portuguese version was established.

\section{Participants}

Patients attended in outpatient care at two Urology Centers were invited to participate in the study. Sixty-three patients of both genders with or without lower urinary tract symptoms (LUTS) were enrolled in the study after appointment, and divided into 2 groups: patients who complained of urgency in the last four weeks and patients who denied having urgency. Urgency was defined in the study as "a strong and sudden desire to void and difficulty avoiding going to the bathroom". All participants who complained of urgency had not been still submitted to $\mathrm{OAB}$ syndrome treatment, and they were not treated up to retest.

We excluded patients under the age of 18 or above the age of 80; patients with an active urinary tract infection, pregnancy, neurological diseases, or other medical conditions that could compromise the perception of bladder sensations; and patients with cognitive impairments.

The recommendations of the American Academy of Orthopaedic Surgeons and Institu- 
te for Work \& Health were used in the cultural adaptation process (18). For the validation study, we used the recommendations of Gorsuch (19) to calculate the sample size required for each domain (minimum subject to item ratio of at least 5:1). Considering the domain "Impact on Daily Activities" that contains the largest number of items (6 items), a minimum sample of 30 patients was required for the process. The institutional ethics committee approved the study, and all of the patients signed an informed consent.

\section{Questionnaires}

The UQ consisted of 15 Likert-type scale items and 4 visual analog scale (VAS) items. The Likert items included 5 responses ranging from "never" to "all the time" and were composed of four subscales (nocturia, fear of incontinence, time to control urgency, and impact on daily activities). The VAS items assessed the severity, intensity, impact, and discomfort of urgency. The higher scores indicated greater intensity of their symptoms. The questionnaire was shown to have validity, reliability and responsiveness (13).

The Overactive Bladder Questionnaire short-form (OABq-SF) has been validated in the Portuguese language, and it was used as the gold standard for this validation study (criterion validity) (9). It consists of 19 questions, which composed two subscales: the "Symptom Bother Scale" (SBS), with 6 questions, and the "Health Related Quality of Life Scale" (HRQL), with 13 questions. A higher score on the SBS indicated a greater degree of dissatisfaction with the condition, and a higher score on the HRQL indicated better quality of life for the patient (20).

\section{Data collection and statistical analysis}

Despite being self-reports, questionnaires were applied rather than interviews to standardize their application and include patients with low levels of education. Sociodemographic and clinical data were collected, and the Portuguese version of the UQ and the OABq-SF were applied. Some patients completed the UQ again 15 days after the baseline.

For the statistical analysis, SPSS software 13.0 and GraphPad Instat ${ }^{\circledR}$ for Windows ${ }^{\circledR}$ and Excel ${ }^{\circledR} 2007$ were used. A Mann-Whitney $\mathrm{U}$ test and paired t-test were used to compare continuous variables, and a Fisher's exact test was used to compare categorical variables. Spearman's rho was used to test the correlation between two continuous variables. The internal consistency of each subscale was tested using the Cronbach's $\alpha$ coefficient. Scores $\geq 0.7$ were considered to be appropriate and excellent when the coefficient was equal to or above 0.8 (21). For all of the tests, an $\alpha$ error $<0.05$ was considered to be statistically significant.

\section{RESULTS}

\section{Participants}

A total of 63 patients were enrolled in the study; 46 of these were symptomatic, and 17 were asymptomatic (control group). The symptomatic patients had a higher mean age compared to the asymptomatic patients, and there was a higher prevalence of constipation in symptomatic patients than asymptomatic patients $(\mathrm{P}<0.0001)$. All of the control subjects were men. There was no difference between the groups for the variables of body mass index (BMI), diabetes, hypertension and history of pelvic/perineal surgery (Table-1).

Symptomatic versus asymptomatic participants

The symptomatic patients had higher scores on all UQ subscales and VAS items compared to asymptomatic patients (Table-2).

\section{Criterion Validity}

The UQ subscales correlated with different scales of the $\mathrm{OABq}-\mathrm{SF}$, except for the subscales "time to control urgency" and the item "impact" from the VAS, which did not show a significant correlation with the OABq-SF - HRQL subscale (Table-3).

\section{Stability}

Fifteen patients completed the test-retest. The re-application of the questionnaire occurred 15 days after visit 1 . Strong correlations were observed between the Visit 1 and 2 scores on the 
Table 1 - Clinical and sociodemographic data of the patients enrolled in the study.

\begin{tabular}{lccc}
\hline Variables & $\begin{array}{c}\text { Symptomatic } \\
(\mathrm{n}=46)\end{array}$ & $\begin{array}{c}\text { Asymptomatic } \\
(\mathrm{n}=17)\end{array}$ & P Value \\
\hline Age (years) & $57.72 \pm 11.31$ & $51.12 \pm 10.75$ & $\mathbf{0 . 0 2}^{*}$ \\
Gender (\% male) & $23(50 \%)$ & $17(100 \%)$ & $<\mathbf{0 . 0 1}^{\text {** }}$ \\
BMI & $28.29 \pm 7.12$ & $27.96 \pm 2.62$ & $0.90^{*}$ \\
Diabetes (\% yes) & $8(13 \%)$ & $3(5 \%)$ & $1.00^{* *}$ \\
Hypertension (\% yes) & $27(43 \%)$ & $8(13 \%)$ & $0.57^{\text {** }}$ \\
Constipation (\% yes) & $19(30 \%)$ & $0(0 \%)$ & $<\mathbf{0 . 0 1}^{\text {** }}$ \\
Perineal/Pelvic Surgery (\% yes) & $18(29 \%)$ & $2(3 \%)$ & 0.06 \\
\hline
\end{tabular}

$\left(^{*}\right)$ Mann-Whitney test; $\left({ }^{\star *}\right)$ Fisher's exact test

Table 2 - Comparative studies of the UQ subscales and VAS items between symptomatic and asymptomatic patients.

\begin{tabular}{lccc}
\hline Urgency Questionnaire & Symptomatic & Asymptomatic & P value \\
\hline Subscales & Median $(Q 1 ;$ Q3) & Median $(Q 1 ; 03)$ & \\
\hline Impact on Daily Activities & $35.42(19.79 ; 66.67)$ & $0.00(0.00 ; 4.17)$ & $<\mathbf{0 . 0 0 1}$ \\
Time to Control Urgency & $68.75(42.19 ; 93.75)$ & $25.00(0.00 ; 50.00)$ & $\mathbf{0 . 0 0 1}$ \\
Nocturia & $62.50(37.50 ; 100.00)$ & $12.50(0.00 ; 18.75)$ & $<\mathbf{0 . 0 0 1}$ \\
Fear of Incontinence & $45.83(16.67 ; 66.67)$ & $0.00(0.00 ; 0.00)$ & $<\mathbf{0 . 0 0 1}$
\end{tabular}

VAS items

\begin{tabular}{llll}
\hline Impact & $7.00(4.75 ; 9.25)$ & $0.00(0.00 ; 4.50)$ & $<\mathbf{0 . 0 0 1}$ \\
Severity & $7.00(4.00 ; 9.00)$ & $0.00(0.00 ; 3.50)$ & $<\mathbf{0 . 0 0 1}$ \\
Intensity & $9.00(6.00 ; 10.00)$ & $0.00(0.00 ; 3.00)$ & $<\mathbf{0 . 0 0 1}$ \\
Discomfort & $9.00(5.00 ; 10.00)$ & $0.00(0.00 ; 1.50)$ & $<\mathbf{0 . 0 0 1}$ \\
\hline
\end{tabular}

Mann-Whitney test

UQ subscales and VAS items, except for "fear of incontinence" and "severity". Spearman's correlations ranging from 0.38 to 0.83 on the UQ subscales and from 0.36 to 0.76 on VAS items were found (Table-4). Nevertheless, there were no statistically significant changes from baseline to visit 2 for any of the subscales and VAS items (Table-5).

\section{Internal consistency}

All four UQ subscales demonstrated adequate to strong internal consistency with alphas ranging from 0.73 to 0.85 (Table-6).

\section{DISCUSSION}

$\mathrm{OAB}$ is a highly prevalent condition with a high economic, social and quality-of-life impact on patients. Therefore, instruments are necessary to evaluate it effectively $(3-5,22,23)$. Because this common medical condition lacks physiological markers and is defined by symptoms rather than objective measures, it is important to assess treatment outcomes from a patient's perspective (24). Consequently, several patient-reported outcome measures have been developed to assess 
Table 3 - Correlation between the scores of the UQ subscales and VAS items and the OABq-SF (criterion validity).

\begin{tabular}{|c|c|c|c|}
\hline Urgency Questionnaire & Spearman's Coefficient & Spearman's Coefficient & \\
\hline Subscales & (OAB-q SF - Symptom Bother Scale) & (OAB-q SF - HRQL) & $P$ value \\
\hline \multirow{2}{*}{ Impact on Daily Activities } & 0.58 & & $<0.0001$ \\
\hline & & -0.74 & $<0.0001$ \\
\hline \multirow{2}{*}{ Time to Control Urgency } & 0.33 & & 0.02 \\
\hline & & -0.28 & 0.06 \\
\hline \multirow{2}{*}{ Nocturia } & 0.77 & & $<0.0001$ \\
\hline & & -0.65 & $<0.0001$ \\
\hline \multirow{2}{*}{ Fear of Incontinence } & 0.55 & & $<0.0001$ \\
\hline & & -0.56 & $<0.0001$ \\
\hline \multicolumn{4}{|l|}{ VAS items } \\
\hline \multirow{2}{*}{ Impact } & 0.32 & & 0.03 \\
\hline & & -0.25 & 0.09 \\
\hline \multirow{2}{*}{ Severity } & 0.62 & & $<0.0001$ \\
\hline & & -0.50 & 0.0004 \\
\hline \multirow{2}{*}{ Intensity } & 0.53 & & 0.0002 \\
\hline & & -0.37 & 0.01 \\
\hline \multirow{2}{*}{ Discomfort } & 0.64 & & $<0.0001$ \\
\hline & & -0.57 & $<0.0001$ \\
\hline
\end{tabular}

Table 4 - Correlation between the scores of the UQ subscales and VAS items at visit 1 and visit 2 (test-retest).

\begin{tabular}{lcc}
\hline Urgency Questionnaire & Spearman's Coefficient & P value \\
\cline { 1 - 2 } Subscales & 0.82 & $\mathbf{0 . 0 0 0 2}$ \\
\hline Impact on Daily Activities & 0.70 & $\mathbf{0 . 0 0 3}$ \\
Time to Control Urgency & 0.83 & $\mathbf{0 . 0 0 0 1}$ \\
Nocturia & 0.38 & 0.16 \\
Fear of Incontinence & & \\
VAS items & 0.52 & $\mathbf{0 . 0 4 6}$ \\
\hline Impact & 0.36 & 0.18 \\
Severity & 0.66 & $\mathbf{0 . 0 0 7}$ \\
Intensity & 0.76 & $\mathbf{0 . 0 0 1}$ \\
Discomfort & & \\
\hline
\end{tabular}


Table 5 - Comparing the scores of the UQ subscales and VAS items at visit 1 and visit 2.

\begin{tabular}{|c|c|c|c|c|c|}
\hline Urgency Questionnaire & \multirow{2}{*}{$\begin{array}{l}\text { Visit } 1 \text { Mean } \\
\text { (SD) }\end{array}$} & \multirow{2}{*}{$\begin{array}{l}\text { Visit } 2 \text { Mean } \\
\quad(S D)\end{array}$} & \multirow{2}{*}{$\begin{array}{l}\text { Mean of } \\
\text { Difference }\end{array}$} & \multirow[t]{2}{*}{ t value } & \multirow[t]{2}{*}{$p$ value } \\
\hline Subscales & & & & & \\
\hline Impact on Daily Activities & $27.8(23.0)$ & $30.6(24.6)$ & 2.8 & 0.68 & 0.50 \\
\hline Time to Control Urgency & $57.9(32.1)$ & $58.3(32.8)$ & 0.40 & 0.06 & 0.95 \\
\hline Nocturia & $59.2(34.5)$ & $56.7(31.6)$ & -2.5 & 0.51 & 0.62 \\
\hline Fear of Incontinence & $29.4(28.5)$ & $30.0(24.2)$ & 0.6 & 0.09 & 0.93 \\
\hline \multicolumn{6}{|l|}{ VAS items } \\
\hline Impact & $6.2(2.8)$ & $5.6(2.7)$ & -0.6 & 0.95 & 0.36 \\
\hline Severity & $5.5(3.1)$ & $5.9(2.6)$ & 0.4 & 0.46 & 0.65 \\
\hline Intensity & $6.5(2.7)$ & $5.1(2.8)$ & -1.4 & 2.14 & 0.06 \\
\hline Discomfort & $6.5(3.0)$ & $6.2(2.8)$ & -0.30 & 0.54 & 0.60 \\
\hline
\end{tabular}

Analyses used paired t-tests comparing responses at visit 1 and visit 2 .

Table 6 - Internal consistency of the Urgency Questionnaire subscales.

\begin{tabular}{lcc}
\hline Urgency Questionnaire & Cronbach's $\alpha$ \\
\hline Subscales & Symptomatic & Symptomatic + Asymptomatic \\
\hline Impact on Daily Activities & 0.842 & 0.891 \\
Time to Control Urgency & 0.852 & 0.899 \\
Nocturia & 0.840 & 0.879 \\
Fear of Incontinence & 0.731 & 0.817 \\
All items & 0.866 & 0.927 \\
\hline
\end{tabular}

$\mathrm{OAB}$ symptoms and their impact on quality of life. However, in order to reliably assess treatment effectiveness, the instrument used to collect patient-reported outcomes must also demonstrate adequate psychometric properties.

Although the comparative analysis between $\mathrm{OAB}-\mathrm{q}$ and UQ has been performed in the present study for the validation process, clinical studies have used both questionnaires simultaneously because they may represent distinct tools that identify different aspects of OAB syndrome (25).

The symptomatic patients were older than the control group, which was justified by the increased prevalence of lower urinary tract symptoms with aging (3). The presence of constipation was higher among symptomatic patients than among asymptomatic patients as well. The higher frequency of this condition in females and older patients might justify this result $(26,27)$.

The UQ is a questionnaire that is validated in English but has not been validated in other languages (13). Another specific-condition questionnaire validated in the Portuguese language was used as the gold standard for establishing the validation criteria. This process evaluated only symptomatic participants, therefore, there was no interference from the absence of asymptomatic women in the present study. Although not all the UQ subscales and VAS items correlated to the scales of the OABq-SF, it does not invalidate the instrument, and it could indicate some differences in what they propose to measure. 
Test-retest reliability is the extent to which an instrument produces stable scores over time. Instruments must have adequate test-retest reliability to ensure that they are consistently measuring the construct of interest without excessive measurement error $(24,28)$. The UQ proved to be stable based on the scores obtained at baseline and after 15 days. Only the subscale "fear of incontinence" and the item "severity" on the VAS showed no correlation between the results from visits 1 and 2. However, there were no statistical changes in any of the subscales from baseline to visit 2. It is also known that how bothersome $\mathrm{OAB}$ symptoms are fluctuates, and changes with daily circumstances. This daily fluctuation creates some variation in the measurement of symptom bother and quality of life, which may be considered measurement error (29).

Reliability refers to the consistency with which an instrument measures a construct, and it is considered to be a necessary measurement property of patient-reported outcome instruments $(24,28,30)$. The UQ was able to differentiate $\mathrm{OAB}$ patients from average, healthy individuals. Internal consistency is an index of consistency across multiple items within a given domain. An adequate consistency was confirmed in the subscales where Cronbach's alpha was calculated. Therefore, the UQ proved to be easily understood when applied as an interview.

The study had some weaknesses. The control group consisted of asymptomatic men only, which could have caused bias. This was due to the greater presence of men without voiding symptoms than women on routine visits. Despite the relatively small sample size, taking into account the significant differences in all of the subscales, conclusions would not have been able to be reached if women had been included in the group. The sample size may have been small to clarify some comparative studies conducted within the limits of the significance level. The calculations, however, were based on previous recommendations for validation studies, which recommend at least 5 patients per item in each domain (19). The questionnaire has been described to be self-reported and should not be administered via interview, even by a previously trained interviewer. Individuals with low educational levels were included, and the method was standardized for illiterate populations. This method has been used in similar validation studies without a significant alteration of the results (16).

\section{CONCLUSION}

The Portuguese version of the UQ represents a comprehensive, valid and reliable instrument for evaluating subjects with $\mathrm{OAB}$, which could be used in clinical studies. Further studies should be conducted to demonstrate its responsiveness.

\section{CONFLICT OF INTEREST}

None declared.

\section{REFERENCES}

1. Banakhar MA, Al-Shaiji TF, Hassouna MM. Pathophysiology of overactive bladder. Int Urogynecol J. 2012;23:975-82.

2. Abrams $P$, Cardozo L, Fall M, Griffiths D, Rosier P, Ulmsten $U$, et al. The standardisation of terminology of lower urinary tractfunction: report from the Standardisation Subcommittee of the International Continence Society. Neurourol Urodyn. 2002;21:167-78.

3. Irwin DE, Milsom I, Hunskaar S, Reilly K, Kopp Z, Herschorn $S$, et al. Population-based survey of urinary incontinence, overactive bladder, and other lower urinary tract symptoms in five countries: results of the EPIC study. Eur Urol. 2006;50:1306-14; discussion 1314-5.

4. Teloken C, Caraver F, Weber FA, Teloken PE, Moraes JF, Sogari $P R$, et al. Overactive bladder: prevalence and implications in Brazil. Eur Urol. 2006;49:1087-92.

5. Sexton CC, Coyne KS, Thompson C, Bavendam T, Chen Cl, Markland $A$. Prevalence and effect on health-related quality of life of overactive bladder in older americans: results from the epidemiology of lower urinary tract symptoms study. J Am Geriatr Soc. 2011;59:1465-70.

6. Milsom I, Abrams P, Cardozo L, Roberts RG, Thüroff J, Wein AJ. How widespread are the symptoms of an overactive bladder and how are they managed? A population-based prevalence study. BJU Int. 2001;87:760-6. Erratum in: BJU Int 2001;88:807.

7. Stewart WF, Van Rooyen JB, Cundiff GW, Abrams P, Herzog $A R$, Corey $R$, et al. Prevalence and burden of overactive bladder in the United States. World J Urol. 2003;20:327-36.

8. Valderas JM, Kotzeva A, Espallargues M, Guyatt G, Ferrans $\mathrm{CE}$, Halyard MY, et al. The impact of measuring patientreported outcomes in clinical practice: a systematic review of the literature. Qual Life Res. 2008;17:179-93. 
9. Acquadro C, Kopp Z, Coyne KS, Corcos J, Tubaro A, Choo MS, et al. Translating overactive bladder questionnaires in 14 languages. Urology. 2006;67:536-40. Erratum in: Urology. 2007;69:202.

10. Kelleher CJ, Cardozo LD, Khullar V, Salvatore S. A new questionnaire to assess the quality of life of urinary incontinent women. Br J Obstet Gynaecol. 1997;104:1374-9.

11. Reese PR, Pleil AM, Okano GJ, Kelleher CJ. Multinational study of reliability and validity of the King's Health Questionnaire in patients with overactive bladder. Qual Life Res. 2003;12:427-42.

12. Coyne KS, Tubaro A, Brubaker L, Bavendam T. Development and validation of patient-reported outcomes measures for overactive bladder: a review of concepts. Urology. 2006;68(2 Suppl):9-16.

13. Coyne KS, Sexton CC, Thompson C, Bavendam T, Brubaker L. Development and psychometric evaluation of the urgency questionnaire for evaluating severity and health-related quality of life impact of urinary urgency in overactive bladder. Int Urogynecol J. 2015;26:373-82.

14. Guillemin F, Bombardier C, Beaton D. Cross-cultural adaptation of health-related quality of life measures: literature review and proposed guidelines. J Clin Epidemiol. 1993:46:1417-32.

15. Tamanini JT, D'Ancona CA, Botega NJ, Rodrigues Netto N $\mathrm{Jr}$. Validation of the Portuguese version of the King's Health Questionnaire for urinary incontinente women. Rev Saude Publica. 2003;37:203-11.

16. de Oliveira MS, Tamanini JT, de Aguiar Cavalcanti G. Validation of the Prolapse Quality-of-Life Questionnaire $(\mathrm{P}-\mathrm{QoL})$ in Portuguese version in Brazilian women. Int Urogynecol J Pelvic Floor Dysfunct. 2009;20:1191-202.

17. Calado AA, Araujo EM, Barroso U Jr, Netto JM, Filho $\mathrm{MZ}$, Macedo A Jr, et al. Cross-cultural adaptation of the dysfunctional voiding score symptom (DVSS) questionnaire for Brazilian children. Int Braz J Urol. 2010;36:458-63.

18. Beaton D, Bombardier C, Guillemin F, Ferraz MB. Recommendations for the Cross-Cultural Adaptation of Health Status Measures [Internet] 1998. Available at: <https://pdfs.semanticscholar.org/729b/ fa6c68a48aafdf61e39e5f9992b155fb8147.pdf>

19. Gorsuch RL. Factor analysis. 2nd ed. Lawrence Erlbaum. Hillsdale; 1983.

20. Coyne KS, Thompson CL, Lai JS, Sexton CC. An overactive bladder symptom and health-related quality of life shortform: validation of the OAB-q SF. Neurourol Urodyn. 2015:34:255-63.
21. Nunnaly J, Bernstein I. Psychometric theory. New York: McGraw-Hill; 1994.

22. Milsom I, Kaplan SA, Coyne KS, Sexton CC, Kopp ZS. Effect of bothersome overactive bladder symptoms on healthrelated quality of life, anxiety, depression, and treatment seeking in the United States: results from EpiLUTS. Urology. 2012;80:90-6

23. Irwin DE, Mungapen L, Milsom I, Kopp Z, Reeves P, Kelleher C. The economic impact of overactive bladder syndrome in six Western countries. BJU Int. 2009;103:202-9.

24. Leidy NK, Revicki DA, Genesté B. Recommendations for evaluating the validity of quality of life claims for labeling and promotion. Value Health. 1999;2:113-27.

25. Chancellor M, Versi E, Dvergsten C, Toler S. Clinical Efficacy and Tolerability of the Nicotinic Channel Modulator Dexmecamylamine in Subjects with Overactive Bladder. J Urol. 2015;194:1329-35.

26. Coyne KS, Sexton CC, Irwin DE, Kopp ZS, Kelleher CJ, Milsom I. The impact of overactive bladder, incontinence and other lower urinary tract symptoms on quality of life, work productivity, sexuality and emotional well-being in men and women: results from the EPIC study. BJU Int. 2008;101:1388-95.

27. Mugie SM, Benninga MA, Di Lorenzo C. Epidemiology of constipation in children and adults: a systematic review. Best Pract Res Clin Gastroenterol. 2011;25:3-18.

28. Guyatt GH, Feeny DH, Patrick DL. Measuring health-related quality of life. Ann Intern Med. 1993;118:622-9.

29. Coyne KS, Matza LS, Thompson CL, Kopp ZS, Khullar V. Determining the importance of change in the overactive bladder questionnaire. J Urol. 2006;176:627-32; discussion 632.

30. Revicki DA, Osoba D, Fairclough D, Barofsky I, Berzon R, Leidy NK, et al. Recommendations on health-related quality of life research to support labeling and promotional claims in the United States. Qual Life Res. 2000;9:887-900.

Correspondence address:

Rodolfo Pacheco de Moraes, MD Divisão de Urologia Hosp. da PM de Pernambuco (PMPE), Derby Rua Antônio de Castro, 150/1302 Recife, PE, 52070-080, Brasil

Telephone: + 5581 99467-1232 E-mail: rodolfopacheco13@yahoo.com 


\section{APPENDIX:}

\section{Validated version of the Urgency Questionnaire in Portuguese}

\section{Questionário de Urgência Miccional}

Esse questionário quer saber sobre as suas experiências quando você sente urgência em urinar. Para cada frase, marque com que frequência você vive esta situação da seguinte maneira: "nenhuma vez, poucas vezes, algumas vezes, na maioria das vezes, ou todas as vezes”. Favor esteja certo(a) de responder cada pergunta marcando um "X" no quadrado apropriado.

Favor pense na semana anterior a esta ao responder à série de afırmações abaixo.

\begin{tabular}{|c|c|c|c|c|c|}
\hline $\begin{array}{l}\text { Durante a semana passada, quando eu senti urgência em urinar } \\
\text { (vontade súbita e forte de urinar e difícil de evitar a ida ao banheiro)... }\end{array}$ & Nenhuma vez & $\begin{array}{l}\text { Poucas } \\
\text { vezes }\end{array}$ & $\begin{array}{l}\text { Algumas } \\
\text { vezes }\end{array}$ & $\begin{array}{l}\text { Na maioria } \\
\text { das vezes }\end{array}$ & $\begin{array}{l}\text { Todas as } \\
\text { vezes }\end{array}$ \\
\hline 1. Consegui controlar esta urgência em urinar por mais de 30 minutos. & $\begin{array}{c}\square \\
1\end{array}$ & $\begin{array}{c}\square \\
2\end{array}$ & $\begin{array}{c}\square \\
\square\end{array}$ & ${ }_{4}^{\square}$ & $\begin{array}{c}\square \\
\square\end{array}$ \\
\hline 2. Consegui controlar esta urgência em urinar por mais de 20 minutos. & $\begin{array}{c}\square \\
1\end{array}$ & $\square$ & $\square$ & $\square$ & $\begin{array}{c}\square \\
5\end{array}$ \\
\hline 3. Consegui controlar esta urgência em urinar por mais de 10 minutos. & $\square$ & $\begin{array}{l}\square \\
2\end{array}$ & $\square$ & $\square$ & $\begin{array}{c}\square \\
5\end{array}$ \\
\hline 4. Consegui controlar esta urgência em urinar por mais de 5 minutos. & $\begin{array}{c}\square \\
1\end{array}$ & $\square$ & $\underset{3}{\square}$ & $\underset{4}{\square}$ & $\begin{array}{c}\square \\
\square\end{array}$ \\
\hline 5. Eu perdi urina sem sentir. & 1 & $\begin{array}{c}\square \\
2\end{array}$ & $\underset{3}{\square}$ & $\underset{4}{\square}$ & $\begin{array}{c}\square \\
5\end{array}$ \\
\hline 6. Fiquei preocupado(a) em "molhar a roupa". & $\begin{array}{c}\square \\
1\end{array}$ & $\begin{array}{c}\square \\
\square\end{array}$ & $\begin{array}{c}\square \\
\square\end{array}$ & $\underset{4}{\square}$ & $\begin{array}{c}\square \\
5\end{array}$ \\
\hline 7. Fui acordado(a) durante o sono para urinar. & $\begin{array}{c}\square \\
\square\end{array}$ & $\begin{array}{c}\square \\
2\end{array}$ & $\begin{array}{c}\square \\
\square\end{array}$ & $\underset{4}{\square}$ & $\begin{array}{c}\square \\
\square\end{array}$ \\
\hline 8. Não consegui realizar atividades ao ar livre (exemplo: caminhada). & $\underset{1}{\square}$ & $\begin{array}{l}\square \\
\square\end{array}$ & $\underset{3}{\square}$ & $\underset{4}{\square}$ & $\underset{5}{\square}$ \\
\hline 9. Eu procurei não me afastar de locais que possuem banheiro perto. & $\underset{1}{\square}$ & $\begin{array}{l}\square \\
\square\end{array}$ & $\underset{3}{\square}$ & $\underset{4}{\square}$ & $\underset{5}{\square}$ \\
\hline 10. Fiquei muito distraído(a) para terminar o que estava fazendo. & $\begin{array}{c}\square \\
\square\end{array}$ & $\begin{array}{c}\square \\
\square\end{array}$ & $\begin{array}{c}\square \\
\square\end{array}$ & $\underset{4}{\square}$ & $\underset{5}{\square}$ \\
\hline 11. Limitei minhas atividades sociais. & $\underset{1}{\square}$ & $\begin{array}{l}\square \\
\square\end{array}$ & $\underset{3}{\square}$ & $\underset{4}{\square}$ & $\underset{5}{\square}$ \\
\hline 12. Meu sono foi frequentemente interrompido. & $\underset{1}{\square}$ & $\begin{array}{c}\square \\
\square\end{array}$ & $\underset{3}{\square}$ & $\underset{4}{\square}$ & $\underset{5}{\square}$ \\
\hline 13. Eu me preocupei com a perda de urina. & $\underset{1}{\square}$ & $\begin{array}{c}\square \\
\square\end{array}$ & $\underset{3}{\square}$ & $\underset{4}{\square}$ & $\underset{5}{\square}$ \\
\hline 14. Tive dificuldades em completar tarefas domésticas diárias. & $\underset{1}{\square}$ & $\frac{\square}{2}$ & $\underset{3}{\square}$ & $\underset{4}{\square}$ & $\underset{5}{\square}$ \\
\hline 15. Tive dificuldades em completar tarefas diárias no trabalho ou na escola. & $\underset{1}{\square}$ & $\underset{2}{\square}$ & $\underset{3}{\square}$ & $\underset{4}{\square}$ & $\underset{5}{\square}$ \\
\hline
\end{tabular}


As perguntas nas páginas seguintes pedem que você classifique seu transtorno com a urgência em urinar em uma escala de ' 0 ' a '10'. Favor responder colocando um "X" em um número da escala que melhor descreve como você se sente, como no exemplo abaixo:

Favor completar as questões de 1-4.

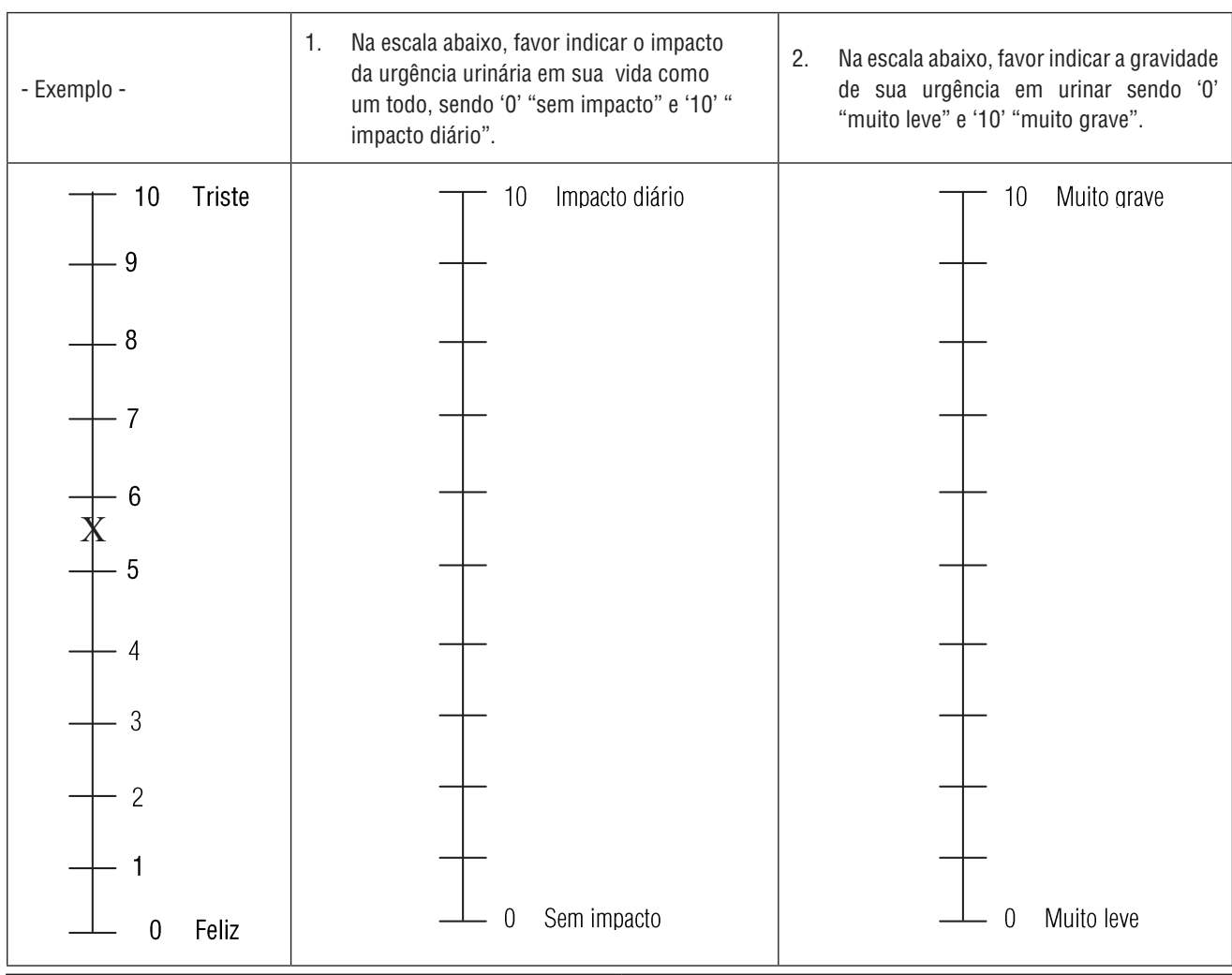

3. Na escala abaixo, favor indicar a intensidade de sua urgência em urinar, sendo '0' "vontade leve e controlável" e ' 10 ' " impossível de controlar (perda de urina todas as vezes que a urgência em urinar surge).

4. Na escala abaixo, favor indicar o desconforto que você sente quando tem urgência em urinar, sendo ' 0 ' "sem desconforto" e '10' "muito desconfortável.
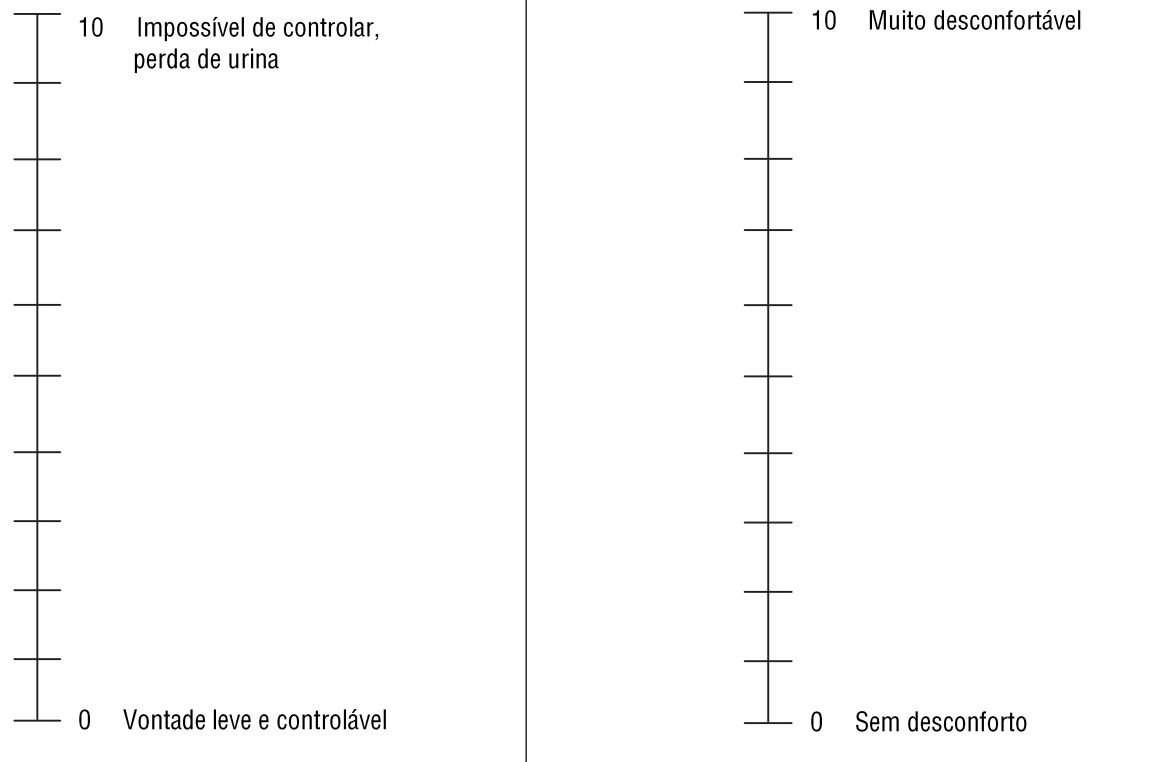